Pediat. Res. 7: 794-797 (1973)

Aerobic metabolism hindlimb

fetus

glucose metabolic regulation

\title{
Glucose/Oxygen Quotients across the Hindlimb of Fetal Lambs
}

\author{
Frank H. Morriss, Jr., Robert D. H. Boyd, Edgar L. Makowski, \\ Giagomo Meschia, and Frederick C. Battaglia ${ }^{[17]}$ \\ Division of Perinatal Medicine, Departments of Obstetrics-Gynecology, Pediatrics, and Physiology, \\ University of Colorado Medical Center, Denver, Colorado, USA
}

\begin{abstract}
Extract
Glucose/oxygen quotients were determined across the hindlimbs of seven fetuses, for a total of five studies in fetuses of fed ewes and five studies in fetuses of fasted ewes. The glucose/oxygen quotient was found to be a function of the fetal arterial glucose concentration in $\mathrm{mm},[\mathrm{a}]$, described by the equation: glucose/oxygen quotient = $-0.047+1.46[\mathrm{a}]$. The dependence of glucose uptake by the fetal hindlimb upon arterial glucose concentration is the first demonstration of the effect of substrate availability on the metabolism of a fetal organ.
\end{abstract}

\section{Speculation}

The demonstration of glucose/oxygen quotients of 1.0 or greater for fetal tissues at a time in gestation when the umbilical glucose/oxygen quotient is $0.4-0.5$ suggests two possible explanations: (1) there may be substrate specificity for oxidative metabolism for each fetal organ, and (2) non-glucose substrates such as amino acids taken up by the umbilical circulation may be utilized by the fetal liver for gluconeogenesis.

\section{Introduction}

Until recently, glucose was considered to be the principal metabolic fuel of the mammalian fetus. However, work from this laboratory has demonstrated that glucose provides, at most, one-half the metabolic substrate for oxidative metabolism in fetuses of well fed ewes [12].

Fructose [12], medium and long chain free fatty acids, and glycerol [7], acetoacetate, and $\beta$-hydroxybutyrate [3] were found to make little or no contribution to the balance of oxidative substrate. On the other hand, the fetal lamb was shown to have a high urea production rate which could account for as much as $25 \%$ of the fetal oxygen consumption through the catabolism of amino acids [5].

In contrast to aerobic metabolic substrate require- ments of the whole fetus as determined by measurements of substrate uptake across the umbilical circulation, glucose could supply all of the aerobic metabolic requirements of the fetal lamb brain in well fed ewes [13]. The discrepancy between the glucose/oxygen quotients for fetal brain and for the fetus as a whole prompted the present study to determine the glucose/ oxygen quotient for a second mass of fetal tissue, the hindlimb.

\section{Materials and Methods}

Seven pregnant Dorset or Western ewes were studied. The ewes were fasted for $48 \mathrm{hr}$ prior to surgery, but allowed water ad libitum. Polyvinyl catheters were advanced to the fetal femoral vein and artery via incisions in the pedal vein and artery, respectively. Each 
vessel was ligated distal to the entry site of the catheter on the dorsal pedal surface. A third polyvinyl catheter was placed in the maternal femoral artery. Correct catheter placement was confirmed at autopsy. Anesthesia and postoperative care were as described previously [8]. The ewes were fed hay and Trophy horse ration [14] ad libitum. All ewes were allowed to recover from surgery for at least 4 days before study of their fetuses.

Five fetuses were then studied while the ewes were well fed. Five fetuses were studied after a subsequent 2-3-day fast.

During each study period five sets of blood samples were drawn at approximately 15-min intervals. Each set consisted of three blood samples of $0.3 \mathrm{ml}$ each drawn simultaneously from maternal artery and fetal femoral artery and vein for glucose determination. An additional 0.3-ml blood sample was withdrawn anaerobically from each fetal catheter in a dry, heparinized glass capillary containing $0.3 \mathrm{mg} \mathrm{NaF}$ for determination of $\mathrm{O}_{2}$ content.

Blood glucose was determined in duplicate by the glucose oxidase method [10] after immediate deproteinization of $0.1 \mathrm{mI}$ blood with zinc sulfate and barium hydroxide. Oxygen content was measured in 0.1 ml blood using a Beckman model GC-2A gas chromatograph equipped with a blood gas accessory.

\section{Data Analysis}

From the data collected during each period of observation, the following differences were calculated: $\Delta$ glucose $=$ fetal femoral artery - fetal femoral vein differ- ence of glucose (millimolar concentration of blood); $\Delta \mathrm{O}_{2}=$ fetal femoral artery - fetal femoral vein difference of oxygen (millimolar concentration of blood). The glucose/oxygen quotient was defined as:

$$
\text { Glucose/oxygen quotient }=\frac{6 \times \Delta \text { glucose }}{\Delta \mathrm{O}_{2}}
$$

This dimensionless quotient represents the fraction of oxygen consumption by the fetal hindlimb required for complete aerobic metabolism of the glucose it consumes [12].

A linear regression equation describing the fetal arterial glucose concentration as a function of the maternal arterial glucose concentration was calculated by the least squares method. Similar calculations were performed to describe the relation between the glucose/oxygen quotient and fetal arterial glucose concentration. To test the significance of the latter association, the Spearman rank correlation coefficient, $r_{s}$, was calculated. This nonparametric test does not require that variables be normally distributed as a condition for statistical validity [11].

\section{Results}

The results are presented in Table I. Maternal arterial blood glucose concentration ranged from $16.8 \mathrm{mg} / 100$ $\mathrm{ml}(0.93 \mathrm{~mm})$ to $49.7 \mathrm{mg} / 100 \mathrm{ml}(2.76 \mathrm{~mm})$, and fetal arterial glucose concentrations ranged from $6.6 \mathrm{mg} /$ $100 \mathrm{ml}(0.37 \mathrm{~mm})$ to $22.9 \mathrm{mg} / 100 \mathrm{ml}(1.27 \mathrm{~mm})$. Figure 1 shows the dependence of fetal concentration, [a], on

Table I. Summary of glucose and oxygen data across fetal sheep hindlimbs

\begin{tabular}{|c|c|c|c|c|c|c|c|c|c|c|c|}
\hline \multirow[b]{2}{*}{ Animal ${ }^{1}$} & \multirow[b]{2}{*}{$\mathrm{GA},{ }^{2}$ days } & \multirow[b]{2}{*}{ Status ${ }^{3}$} & \multirow[b]{2}{*}{$\begin{array}{l}\text { Weight at } \\
\text { autopsy, kg }\end{array}$} & \multicolumn{4}{|c|}{ Glucose, $\mathrm{mm}$} & \multicolumn{3}{|c|}{ Oxygen, $\mathrm{mm}$} & \multirow{2}{*}{$\begin{array}{l}\text { Glucose/ } \\
\text { oxygen } \\
\text { quotient }\end{array}$} \\
\hline & & & & $\begin{array}{l}\text { Maternal } \\
\text { femoral } \\
\text { artery }\end{array}$ & $\begin{array}{c}\text { Fetal } \\
\text { femoral } \\
\text { artery }\end{array}$ & $\begin{array}{c}\text { Fetal } \\
\text { femoral } \\
\text { vein }\end{array}$ & $\Delta$ Glucose & $\begin{array}{c}\text { Fetal } \\
\text { femoral } \\
\text { axtery }\end{array}$ & $\begin{array}{c}\text { Fetal } \\
\text { femoral } \\
\text { vein }\end{array}$ & $\Delta \mathrm{O}_{2}$ & \\
\hline \multirow[t]{2}{*}{$W 72-009-(2)$} & 136 & $\mathrm{~F}$ & 2.85 & 2.06 & 0.64 & 0.56 & 0.08 & 3.30 & 2.79 & 0.51 & 0.94 \\
\hline & 138 & $\mathrm{~S}_{2}$ & & 0.93 & 0.37 & 0.32 & 0.05 & 4.42 & 2.74 & 1.68 & 0.18 \\
\hline \multirow[t]{2}{*}{ D72-015-(1) } & 135 & $\mathrm{~F}$ & 3.67 & 2.76 & 1.03 & 0.68 & 0.35 & 2.48 & 1.17 & 1.31 & 1.60 \\
\hline & 138 & $\mathrm{~S}_{3}$ & & 1.53 & 0.72 & 0.47 & 0.25 & 1.55 & 0.62 & 0.93 & 1.61 \\
\hline \multirow[t]{2}{*}{$D 72-016-(1)$} & 137 & $\mathrm{~F}$ & 3.96 & 2.63 & 0.67 & 0.62 & 0.05 & 3.39 & 2.82 & 0.57 & 0.53 \\
\hline & 139 & $\mathrm{~S}_{2}$ & & 2.18 & 0.66 & 0.58 & 0.08 & 4.72 & 4.23 & 0.49 & 0.98 \\
\hline$D 72-027-(1)$ & 136 & $F$ & 3.55 & - & 1.27 & 1.05 & 0.22 & 3.71 & 2.91 & 0.80 & 1.65 \\
\hline$W 72-039-(1)$ & 130 & $\mathrm{~S}_{3}$ & 2.54 & 2.66 & 0.98 & 0.80 & 0.18 & 2.78 & 1.91 & 0.87 & 1.24 \\
\hline$W 72-038-(1)$ & 126 & $\mathrm{~S}_{3}$ & 2.44 & 1.74 & 0.80 & 0.54 & 0.26 & 4.09 & 2.57 & 1.52 & 1.03 \\
\hline$W 72-058-(2)$ & 124 & $F$ & 1.30 & 1.25 & 0.49 & 0.30 & 0.19 & 2.90 & 1.61 & 1.29 & 0.88 \\
\hline Mean & 133.9 & & 2.90 & 1.97 & 0.76 & 0.59 & 0.17 & 3.33 & 2.34 & 1.00 & 1.06 \\
\hline$\pm \mathrm{SEM}$ & \pm 1.68 & & \pm 0.35 & \pm 0.22 & \pm 0.09 & \pm 0.07 & \pm 0.03 & \pm 0.30 & \pm 0.33 & \pm 0.14 & \\
\hline
\end{tabular}

1 (1): singleton; (2): twin.

${ }^{2} \mathrm{GA}$ : gestational age.

${ }^{3} \mathrm{~F}$ : fed; $\mathrm{S}_{2}$ : fasted for 2 days; $\mathrm{S}_{3}$ : fasted for 3 days. 




Fig. 1. Simple linear regression describing the relation between maternal arterial blood glucose concentration, [A], and fetal arterial blood glucose concentration, [a].

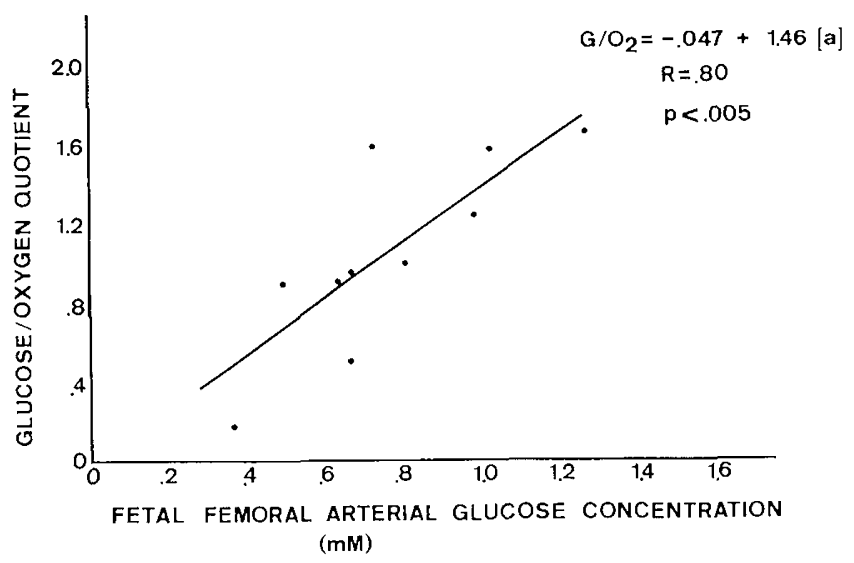

Fig. 2. Simple linear regression describing the relation between fetal femoral artery blood glucose concentration, [a], and glucose/ oxygen quotient of the hindlimb, $\mathrm{G} / \mathrm{O}_{2}$.

maternal concentration, $[\mathrm{A}]$, in $\mathrm{mm}$. The regression equation is:

$$
[\mathrm{a}]=0.21+0.25[\mathrm{~A}] \quad(\mathrm{R}=0.79 ; P<0.005)
$$

Fetal hindlimb glucose/oxygen quotients ranged from 0.19 to 1.68 and were found to vary with fetal arterial glucose concentration, as shown in Figure 2. The regression equation for this relation is:

$$
\begin{gathered}
\text { Glucose/oxygen quotient }=--0.047+1.46[\mathrm{a}] \\
(\mathrm{R}=0.80 ; P<0.005)
\end{gathered}
$$

The Spearman rank correlation coefficient, $r_{s}$, equals $0.86(P=0.001)$.

\section{Discussion}

A linear relation between maternal and fetal arterial glucose concentrations was demonstrated in previous studies from this laboratory [8] and has been confirmed in the present study (see Equation 2).

Equation 3 describes the relation between the fetal arterial glucose concentration and the utilization of glucose by the hindlimb to meet its substrate needs for oxidative metabolism. The greater the arterial concentration of glucose, the greater the glucose uptake by the hindlimb relative to oxygen consumption. In fact, at concentrations greater than $\sim 0.7 \mathrm{~mm}$, more glucose is taken up by the hindlimb than is required for aerobic metabolism. On the other hand, during maternal fasting when fetal glucose concentrations are decreased, glucose is not the sole substrate for aerobic metabolism of the hindlimb.

The dependence of glucose uptake by the fetal hindlimb upon arterial glucose concentration is the first demonstration of the effect of substrate availability on the metabolism of a fetal organ. Acute studies performed on isolated perfused brains from adult dogs have shown that glucose uptake by the brain is a function of concentration of arterial glucose [4]. Similarly, cerebral uptakes of acetoacetate and $\beta$-hydroxybutyrate in both adult and suckling rats were found to be dependent upon the arterial concentration of these ketone bodies [6].

However, studies of adult human forearm metabolism during fasting have demonstrated that, although the arterial concentrations of acetoacetate and $\beta$-hydroxybutyrate are increased throughout a 24-day period of fasting, the uptakes of these compounds are increased markedly only during the acute period (3 days) of fasting. The availability of high arterial concentrations of free fatty acids resulted in their apparently preferential utilization as an oxidative substrate at 24 days of fasting [9]. Thus, the observation of the dependence of glucose uptake by the fetal sheep hindlimb upon arterial glucose concentration is valid for fetuses of well fed and acutely fasted ewes, but may not be true in chronic starvation.

The mean fetal arterial glucose concentration for another 37 unstressed sheep fetuses of well fed ewes determined during 62 total study periods in our laboratory $[2,8,12]$ is $1.03 \mathrm{~mm} \pm 0.14 \mathrm{mM}$, with $95 \%$ confidence limits for fetal arterial glucose concentration of $0.75,1.31$. The mean glucose/oxygen quotient for the four fetuses in the present study with arterial glucose concentrations within these $95 \%$ confidence 
limits is 1.39 , which indicates that all of the substrate requirement for oxidative metabolism in the hindlimb of fetuses of well nourished ewes could be supplied by glucose. However, this finding does not exclude the utilization of other substrates. A significant fraction of glucose taken up by the hindlimb could be utilized anaerobically, or for the formation of glycogen, or for growth.

\section{Summary}

Glucose uptake by fetal sheep hindlimbs is regulated by the fetal arterial glucose concentration, which is a function of maternal arterial glucose concentration. In the hindlimb of fetuses of well nourished ewes, the uptake of glucose exceeds the requirements of oxidative metabolism.

\section{References and Notes}

1. Ballard, F. J., AND Oliver, I. T.: Carbohydrate metabolism in liver from foetal and neonatal sheep. Biochem. J., 95: 191 (1965).

2. Boyd, R. D. H., Morriss, F. H., JR., Meschia, G. Makowski, E. L., AND Battaglia, F. C.: Growth of glucose and oxygen uptakes by the fetuses of fed and starved ewes. Amer. J. Physiol. (In press.)

3. Boyd, R. D. H., Morriss, F. H., Jr., Meschia, G., Makowski, E. L., And Battaglia, F. C.: A-V differences of $\beta$-hydroxybutyrate and acetoacetate in the ovine umbilical circulation. (In preparation.)

4. Gilboe, D. D., Andrews, R. L., and Dardenne, G.: Factors affecting glucose uptake by the isolated dog brain. Amer. J. Physiol., 219: 767 (1970).

5. Gresham, E. L., James, E. J., Raye, J. R., Batraglia, F. C.,
Makowski, E. L., AND Meschia, G.: Production and excretion of urea by the fetal lamb. Pediatrics, 50: 372 (1972).

6. Hawkins, R. A., Williamson, D. H., and Krebs, H. A.: Ketone-body utilization by adult and suckling rat brain in vivo. Biochem. J., 122: 13 (1971).

7. James, E., Meschia, G., and Battaglia, F. C.: A-V differences of free fatty acids and glycerol in the ovine umbilical circulation. Proc. Soc. Exp. Biol. Med., 138: 823 (1971).

8. James, E., Raye, J. R., Gresham, E. L., Makowski, E. L., Meschia, G., and Battaglia, F. C.: Fetal oxygen consumption, carbon dioxide production, and glucose uptake in a chronic sheep preparation. Pediatrics, 50: 361 (1972).

9. Owen, O. E., ANd Reichard, G. A., JR.: Human forearm metabolism during progressive starvation. J. Clin. Invest., 50: 1536 (1971).

10. Saifer, A., and Gerstenfeld, S.: The photometric microdetermination of blood glucose with glucose oxidase. J. Lab. Clin. Med., $51: 448$ (1958).

11. Siegel, S.: Nonparametric Statistics for the Behavioral Sciences, p. 202-213 (McGraw-Hill, New York, 1956).

12. Tsoulos, N. G., Colwill, J. R., Batraclia, F. C., Makowski, E. L., AND Meschia, G.: Comparison of glucose, fructose, and $\mathrm{O}_{2}$ uptakes by fetuses of fcd and starved ewes. Amer. J. Physiol., 221: 234 (1971).

13. Tsoulos, N. G., Schneider, J. M., Colwill, J. R., Meschia, G., Makowski, E. L., ANd Battaglia, F. C.: Cerebral glucose utilization during aerobic metabolism in fetal sheep. Pediat. Res., 6: 182 (1972).

14. Albers Milling Company, Division of Carnation Company, Los Angeles, Calif.

15. Dr. Robert D. H. Boyd was supported by Goldsmith's Travelling Fellowship of the Medical Research Council. This research was supported by United States Public Health Service Grants HD-00781 and HD-01866.

17. Requests for reprints should be addressed to: Frederick C. Battaglia, M.D., Division of Perinatal Medicine, Container 2302, University of Colorado Medical Center, $4200 \mathrm{E}$. Ninth Ave., Denver, Colo. 80220 (USA).

18. Accepted for publication May 15, 1973. 